\title{
Peningkatan Hasil Belajar Gerak Dasar, Pembelajaran Bermain Kata Sandi Siswa SD Negeri 47 Kota Jambi
}

\author{
Dr. Drs. H. Sukendro, M.Kes, AIFO \\ Correspondence: Fakultas Ilmu Keolahragaan, Universitas Jambi, Jambi, \\ Indonesia. \\ E-mail: sukendrodasar@yahoo.co.id
}

\begin{abstract}
Abstrak
Tujuan penelitian ini adalah untuk mengetahui peningkatan hasil pembelajaran gerak dasar menggunakan permainan kata sandi pada siswa kelas III SD Negeri 164/III Perikan Tengah Kecamatan Gunung Raya Tahun Ajaran 2016/2017. Metode dalam penelitian ini adalah PTK dengan teknik tes dan pengukuran menggunakan tes gerak dasar. Instrumen dalam penelitian ini adalah tes melempar sasaran, lompat jauh tanpa awalan, lari zig-zag, kesetimbangan statis, tes, lentuk togok. Hasil uji hipotesis dengan menggunakan rumus uji-t diperoleh nilai t-hitung = 11,77: Nilai ini dibandingkan dengan nilai t-tabel $(d k=n-1=23 ; \square=0,05)$ diperoleh 1,68. Sehingga diperoleh t-hitung $>t$-tabel, dengan demikian hipotesis yang menyatakan: Pembelajaran bermain kata sandi terdapatpeningkatkan terhadap hasil belajar gerak dasar pada siswa kelas III SD Negeri 164/III Perikan Tengah Kecamatan Gunung Raya Tahun Ajaran 2016/2017 dapat diterima kebenarannya. Berdasarkan data nilai rata-rata pre-test dan pos-test diperoleh hasil bahwa kemampuan gerak dasar setelah proses pembelajaran bermain kata sandi lebih baik dari pada data pre-test di kelas III SD Negeri 164/III Perikan Tengah Kecamatan Gunung Raya Tahun Ajaran 2016/2017.
\end{abstract}

\section{Kata Kunci: Kata Sandi, Gerak Dasar}

\section{Pendahuluan}

Pendidikan Jasmani merupakan bagian integral dari pendidikan secara keseluruhan yang bertujuan untuk mengembangkan aspek kebugaran jasmani, keterampilan gerak, keterampilan berfikir kritis, kemampuan sosial, penalaran, stabilitas emosional, tindakan moral, aspek pola hidup sehat dan pengenalan lingkungan bersih melalui aktifitas jasmani, olahraga dan kesehatan terpilih yang direncanakan secara sistimatis dalam rangka mencapai tujuan pendidikan nasional.

Pendidikan jasmani adalah suatu proses pendidikan yang dilakukan secara sadar dan sistematis melalui berbagai aktivitas jasmani dalam rangka memperoleh kemampuan dan keterampilan jasmani, pertumbuhan fisik, kecerdasan dan pertumbuhan watak. Sebagai sub sistem dari pendidikan nasional, kegiatan jasmani di sekolah wajib diikuti oleh semua siswa.

Tujuan pendidikan jasmani di sekolah adalah membantu siswa dalam peningkatan kesegaran jasmani melalui pengenalan dan penanaman sikap positif serta kemampuan gerak dari berbagai aktivitas jasmani, sedangkan fungsi dari Pendidikan jasmani yang disajikan di sekolah memiliki fungsi antara

PJKR_

http://jurnal.unimed.ac.id/2012/index.php/jpehr/index 
pengembangan aspek: (a) organic, (b) neuro moscular, (c) perceptual, (d) social dan (e) emosional (Depdiknas : 2003:34).

Salah satu dari ciri-ciri makhluk hidup adalah kemampuannya untuk melakukan gerak. Manusia, hewan, tumbuhan adalah makhluk hidup dan mempunyai kemampuan untuk melakukan gerak. Semakin banyak gerak yang mampu dilakukan oleh tubuh, semakin berkualitas hidup manusia.

Gerak yang dilakukan manusia bermacam-macam jenisnya, dari gerak yang paling sederhana seperti gerak yang dilakukan bayi dalam kandungan dan setelah lahir ke dunia, gerak dasar seperti gerak lokomotor, gerak non lokomotor serta gerak manipulatif yang dilakukan anak-anak sampai usia sekolah dasar, dan gerak sempurna yang dilakukan manusia dewasa.

Pendidikan Jasmani memiliki peranan yang penting dalam pembinaan dan pengembangan siswa SD. Mata pelajaran Pendidikan Jasmani lebih mengutamakan aktivitas gerak yang mempunyai tujuan untuk meningkatkan pertumbuhan dan perkembangan serta kesehatan untuk memenuhi kebutuhan hidup individu. Pendidikan jasmani berperan sebagai sarana pembinaan dan pengembangan individu maupun kelompok dalam menunjang pertumbuhan dan perkembangan jasmani, kesehatan, mental, sosial serta emosional yang serasi, selaras dan seimbang.

Kemampuan gerak merupakan tingkatan kemampuan yang lebih kompleks dari berbagai kerja sama sistem tubuh dalam menampilkan gerak, atau kemampuan melakukan tugas gerak dengan efisien. Hal ini sesuai dengan salah satu tujuan pemberian pelajaran pendidikan jasmani kepada siswa adalah agar siswa menjadi terampil dalam melakuan aktivitas fisik. Kemampuan gerak yang diperoleh melalui pelaksanaan pendidikan jasmani berguna dalam penguasaan cabang olahraga tertentu dan dalam melakukan tugas fisik dalam kehidupan sehari-hari.

Gerak merupakan sesuatu yang ditampilkan manusia secara nyata dan dapat diamati, namun yang melatar belakangi suatu gerak yang ditampilkan dalam suatu perbuatan yang nyata dan dalam suatu pekerjaan sangat beraneka ragam sesuai dengan hakikat keberadaan dan kebutuhan hidup manusia yang berbedabeda.

Peningkatan hasil belajar gerak pada siswa SD dirasakan semakin penting artinya, sehubungan dengan peranannya dalam meningkatkan kemampuan intelektual peserta didik. Hal ini berhubungan dengan hakikat inti dari pendidikan jasmani sebagai wadah dalam peningkatan kemampuan gerak siswa.

Kata sandi menurut kaidah kamus bahasa Indonesia adalah kata atau tanda yang dibuat dengan maksud atau tujuan tertentu dan sering juga disebut dengan kode rahasia. Bermain kata sandi pada anak-anak sering dilakukan, dengan tujuan agar teman yang lain tidak mengetahui apa yang mereka maksud. Dengan bermain kata sandi pada siswa sekolah dasar diharapkan akan meningkatkan motivasinya dalam bergerak, yang pada akhirnya akan dapat mengembangkan kemampuan motoriknya.

Sehubungan dengan uraian di atas, ditambah dengan pentingnya peningkatan kemampuan gerak dasar siswa sekolah dasar melalui permainan-

PJKR_

http://jurnal.unimed.ac.id/2012/index.php/jpehr/index 
permainan yang sesuai dengan tingkatan umur dan kemampuan anak, maka penulis merasa tertarik untuk mengangkat judul "Upaya Meningkatkan Hasil Belajar Gerak Dasar Menggunakan pembelajaran bermain kata sandi pada siswa kelas III SD Negeri 47/IV Kota Jambi”.

Tujuan yang diharapkan dengan pelaksanaan penelitian ini adalah untuk mengetahui Peningkatan hasil belajar gerak dasar melalui pembelajaran bermain kata sandi pada siswa kelas III SD Negeri 47/IV Kota Jambi.

\section{Pustaka}

Kemampuan gerak merupakan tingkatan kemampuan yang lebih kompleks dari berbagai kerja sama sistem tubuh dalam menampilkan gerak, atau kemampuan melakukan tugas gerak dengan efisien. Hal ini sesuai dengan salah satu tujuan pemberian pelajaran pendidikan jasmani kepada siswa adalah agar siswa menjadi terampil dalam melakuan aktivitas fisik. Kemampuan gerak yang diperoleh melalui pelaksanaan pendidikan jasmani berguna dalam penguasaan cabang olahraga tertentu dan dalam melakukan tugas fisik dalam kehidupan sehari-hari. Kemampuan gerak itu sendiri dapat berfungsi sebagai kapabilitas yang dihubungkan dengan input/masukan (aktivitas sensoris perseptual), pusat pemrosesan (mangorganisasi manajemen, dan pembuatan keputusan) dan fungsi gerak dan penggunaan umpan balik dari masukan (Kiram, $1992: 31$ ).

Gerak yang disebutkan mencakup arti yang sangat luas, dimana gerak itu sendiri memiliki tingkatan yang berbeda-beda. Blanc Lowy dalam Sukintaka (1992:47) mengutarakan hubungan antara umum perkembangan, tahap penguasaan perbuatan dan perbuatan karakteristik, yang dapat dilihat pada tabel sebagai berikut:

Tabel 1. Tahap Prilaku Gerak (Motor Behavior)

\begin{tabular}{|l|l|l|}
\hline \multicolumn{1}{|c|}{ Terminal } & \multicolumn{1}{c|}{ Tahap } & \multicolumn{1}{c|}{ Contoh Laku Karakteristik } \\
\hline $\begin{array}{l}\text { Masa anak-anak } \\
\text { (0-2 tahun) }\end{array}$ & Gerak tidak sempurna & $\begin{array}{l}\text { Berguling, duduk, merayap, } \\
\text { merangkak, berdiri, berjalan dan } \\
\text { memegang. }\end{array}$ \\
$\begin{array}{l}\text { Masa anak-anak awal } \\
\text { (2-7 tahun) }\end{array}$ & $\begin{array}{l}\text { Gerak dasar } \\
\text { dan pemahaman efisiensi) }\end{array}$ & $\begin{array}{l}\text { Lokomotor, nonlokomotor, manipulasi } \\
\text { dan kesadaran gerak. }\end{array}$ \\
$\begin{array}{l}\text { Masa anak-anak tengah } \\
\text { bagian akhir (8-12 } \\
\text { tahun) }\end{array}$ & Khusus (khas) & $\begin{array}{l}\text { Penghalusan Kemampuan gerak dan } \\
\text { penyadaran gerak, menggunakan dasar } \\
\text { gerak dalam tari tertentu, permainan } \\
\text { atau olahraga, senam, dan kegiatan } \\
\text { olahraga air. }\end{array}$ \\
$\begin{array}{l}\text { Masa remaja dan masa } \\
\text { dewasa (12-dewasa) }\end{array}$ & Spesialisasi & Bersifat rekreasi. \\
\hline
\end{tabular}

(Sumber: Blanc dan Lowy dalam Sukintaka, 1992 : 47)

Dari tabel di atas Blanc dan Lowy menjelaskan bahwa gerak tidak sempurna ialah gerak dimulai sejak saat dekat sesudah lahir sampai anak umur 2

PJKR_ 
tahun. Beberapa kegiatan yang khas pada saat ini ialah merayap, merangkak, berjalan dan bergerak yang disadari. Gerak dasar, ada masa ini anak membentuk dasar untuk gerak. Dasar untuk gerak, dasar untuk kemampuan meliputi gerak lokomotor, nonlokomotor, manipulasi dan menyadari gerak, yang akan merupakan dasar macam-macam kemampuan, dan dapat melaksanakannya dengan tangkas. Bagi anak normal, kebanyakkan semua kemampuan dan pemahaman itu akan dikaitkan dengan masalah dasar gerak, sehingga anak akan memperoleh beberapa ketangkasan pada masa akhir tahap ini kira-kira pada umur tujuh tahun. Kemampuan dasar, merupakan kegiatan gerak yang umum yang bertujuan umum untuk lari, lompat dan loncat, melempar atau menerima. Kemampuan gerak dasar merupakan dasar untuk lebih mengembangkan aktifitas gerak yang lebih spesifik, yang biasa disebut kegiatan olahraga.

Menurut Sukintaka (1992 : 47) mengingat salah satu tujuan umum pendidikan jasmani di sekolah dasar menyangkut aspek fisik yaitu membentuk dan mengembangkan kemampuan gerak, maka perlulah diperoleh pengertian yang lebih jelas tentang unsur-unsur kemampuan gerak dasar yakni keseimbangan, kelentukan dan kelincahan, sebagai berikut: Menurut Kiram, (1992 : 42) Keseimbangan merupakan terjemahan dari kata "Balance" yang mempunyai arti kemampuan tubuh untuk mempertahankan posisi dalam bermacam-macam gerakan. Keseimbangan merupakan kualitas kemampuan gerak yang kompleks, kemampuan tersebut dipengaruhi oleh bermacam-macam faktor yakni penglihatan, peradaban dan fungsi vertibuler. Mulai usia 7 tahun pada umumnya anak dapat melakukan keseimbangan, dan semakin bertambahnya usianya mereka makin baik keseimbangan. Keseimbangan sangat dibutuhkan untuk melakukan gerakan pada cabang-cbang olahraga yang memerlukan perubahan gerak secara tiba-tiba. Untuk mengembangkan kemampuan seseorang menjaga keseimbangan dapat melalui berbagai aktivitas baik pada pembelajaran pendidikan jasmani maupun olahraga. Apabila dalam melakukan keseimbangan, tampak kaki penunjangnya gemetar dengan demikian pelaku gerakan tersebut tidak dapat mempertahankan kontraksi otot-otot fleksor dan ekstensor pada kaki untuk mempertahankan posisi berdirinya.

Kata kelentukan sebagai terjemahan dari kata "Flexibility" adalah keefektivan seseorang dalam penyesuaian diri untuk melakukan segala aktivitas tubuh dengan penguluran seluas-luasnya, terutama otot-otot ligmen di sekitar persendian tanpa menimbulkan gangguan pada bagian tersebut. Kelentukan ada dua cara yaitu statis dan dinamis. Kelentukan statis meliputi rentangan gerakan sederhana, seperti tunduk perlahan-lahan dan menyentuh ujung kaki. Kelentukan dinamis adalah kecakapan untuk menggunakan rentangan gerakan pada sendi dalam melakukan aktivitas fisik, dengan kecepatan yang diperlukan. Seseorang yang kurang kelentukannya biasanya mudah lelah dan gerakannya kaku serta lambat dalam belajar Kemampuan fisik (Paterson Hallberg, eds dalam Harsono, 1997 : 69) berdasarkan pendapat tersebut, kelentukan sebagai salah satu unsur kemampuan gerak yang menyangkut kapasitas fungsional sesuatu persendian mempunyai pengaruh besar terhadap keluwesan gerak. 
Kelincahan atau agility adalah kemampuan seseorang, dalam mengubah arah dengan posisi tertentu dengan cepat dan tepat. Seseorang yang mampu mengubah posisi yang berbeda dengan kecepatan tinggi dan koordinasi gerak yang baik berarti kelincahannya cukup tinggi. Kelincahan merupakan salah satu faktor yang sangat penting dalam melakukan aktivitas olahraga serta dalam kehidupan sehari-hari. Semua bentuk permainan memerlukan kelincahan, adapun pelatihan untuk meningkatkan kelincahan banyak macamnya misalnya lari dengan berubah-ubah arah pada setiap ada aba-aba, lari berkelok-kelok dan sebagainya. Bentuk-bentuk pelatihan kelincahan pada dasarnya banyak disukai oleh anak tingkat sekolah dasar. Semua itu tergantung bagaimana guru dapat menarik perhatian peserta didiknya, agar peserta didik gemar terhadap materi yang disajikan.

Dalam Kamus Umum Bahasa Indonesia karangan Poerwadarminta diterangkan bahwa kata sandi mempunyai arti sebagai kata atau tanda yang dibuat dan mempunyai maksud atau arti tertentu. Kata sandi sering juga disebut dengan kode (Poerwadarminta, 1986:865). Dalam proses pembelajaran di sekolah dasar, pembelajaran dengan menggunakan kata sandi masih jarang dilakukan. Hal ini disebabkan masih kurangnya perbendaharaan kata sandi yang ada, sehingga pembelajaran masih sukar dilakukan.

Proses pembelajaran gerak dasar di sekolah dasar dapat ditingkatkan melalui permainan kata sandi. Kata sandi biasanya dicirikan oleh kemudahan untuk dipahami, disepakati, dapat meningkatkan penguasaan kata-kata (perbendaharaan kata). Bahasa sandi dapat dibuat dengan cara-cara sebagai berikut: 1. Dengan cara membalik suku kata yang ada, 2. Dengan cara membaca hurup dari kanan, 3. Menyisipkan beberapa hurup diantara hurup-hurup dari perkataan yang diucapkan. 4. Dengan cara memberi lambang hurup atau angka menggantikan suatu kata atau kalimat dan 5. Dengan cara membalik abjad (Sukintaka, 1992:29).

Kata sandi mempunyai arti sebagai perkataan atau istilah dalam bentuk lambang berupa angka atau huruf yang dibuat dan mempunyai maksud atau arti tertentu. Kata sandi sering juga disebut dengan kode. Dalam proses pembelajaran di sekolah dasar, pembelajaran dengan menggunakan kata sandi masih jarang dilakukan. Hal ini disebabkan masih kurangnya perbendaharaan kata sandi yang ada, sehingga pembelajaran masih sukar dilakukan. Proses pembelajaran gerak dasar di sekolah dasar dapat ditingkatkan melalui permainan kata sandi. Kata sandi biasanya dicirikan oleh kemudahan untuk dipahami, disepakati, dapat meningkatkan penguasaan kata-kata (perbendaharaan kata).

Berdasarkan uraian tentang pengertian kata sandi serta permainan kata sandi yang akan peneliti lakukan, dapat disimpulkan bahwa melalui permainan kata sandi yang akan dilakukan berupa kata sandi gerak lokomotor, non lokomotor dan gerak manifulatif akan mempengaruhi perkembangan gerak dasar anak. Hal ini disebabkan melalui permainan yang diadakan, anak akan tertarik dan bersemangat melakukannya.

\section{Metode}

PJKR_

http://jurnal.unimed.ac.id/2012/index.php/jpehr/index 
Metode penelitian ini adalah Metode Penelitian Tindakan kelas (classroom action research). Yaitu penelitian yang dilakukan oleh guru dikelasnya sendiri melalui refleksi diri dengan tujuan untuk memperbaiki kinerjanya sehingga hasil belajar siswa meningkat. Pendekatan yang digunakan adalah pendekatan kualitatif yang berguna untuk mengungkapkan kesulitan belajar siswa dalam proses pembelajaran pendidikan jasmani serta cara mengatasi kesulitan - kesulitan tersebut sebagai upaya untuk meningkatkan hasil belajar siswa pada materi tersebut. Penelitian ini dilaksanakan di SD Negeri 47/IV Kota Jambi, Kec Telanaipura, pada awal penelitian diikuti dengan proses pembelajaran hingga pelaksanaan post test. Subjek dalam penelitian ini adalah seluruh siswa kelas III SD Negeri 47/IV Kota Jambi dengan jumlah siswa sebanyak 24 orang.

Desain penelitian yang dilaksanakan adalah desain yang digambarkan oleh Arikunto, dkk (2006:16) yang mengemukakan secara garis besar terdapat 4 (empat) tahapan yang dilalui dalam melaksanakan penelitian tindakan kelas (PTK), yaitu : 1) Perencanaan, 2) Pelaksanaan, 3) Pengamatan, 4) Refleksi. Adapun model tahapannya adalah sebagai berikut:

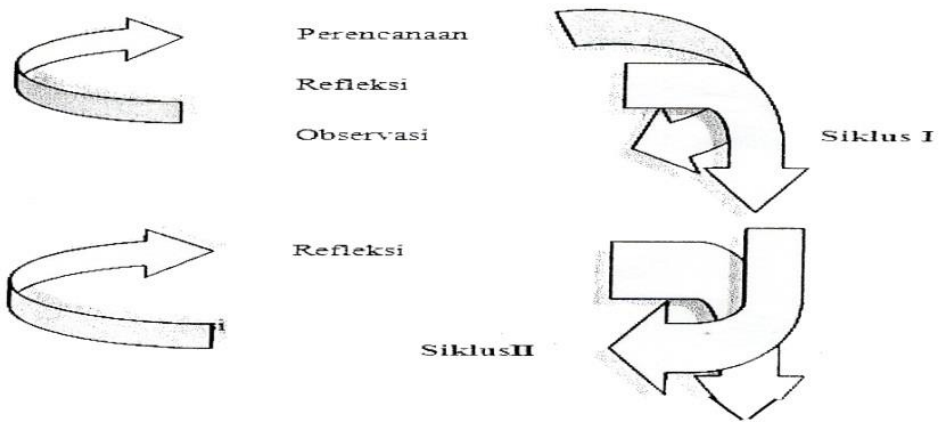

Gambar 1. Desain dalam Pendidikan Jasmani dan Kepelatihan Olahraga, (Agus Kristiyanto, 2010:19).

Analisis data yang dilakukan terdiri dari beberapa tahap diantaranya :

1. Reduksi Data, proses reduksi data dilakukan dengan cara menyeleksi, menyederhanakan dan mentransformasikan data yang telah disajikan dalam transkip catatan lapangan. Kegiatan reduksi data ini bertujuan untuk melihat kesalahan atau kekurangan siswa dalam pelaksanaan tes dan tindakan apa yang akan dilakukan untuk perbaikan kesalahan tersebut.

2. Paparan Data, dalam kegiatan ini data yang diperoleh dari hasil belajar siswa dipaparkan dalam bentuk tabel dengan menggunakan rumus yang telah ditetapkan. Seperti yang diterangkan dibawah ini: Mencari persentase kemampuan siswa digunakan rumus

$$
K K M=\frac{B}{N} X 100 \%
$$

Keterangan :

KKM : Kriteria Ketuntasan Minimal

B : Skor yang diperoleh

N : Skor total

PJKR_

http://jurnal.unimed.ac.id/2012/index.php/jpehr/index 
Dengan kriteria:

$0 \leq \mathrm{KKM}<70 \quad=$ Siswa belum tuntas dalam belajar

$70 \leq \mathrm{KKM} \leq 100 \quad=$ Siswa sudah tuntas dalam belajar

(Nurkencana dalam Yuri, 2009: 29)

Dari uraian diatas dapat diketahui siswa yang belum tuntas dalam belajar dan siswa yang sudah tuntas dalam belajar secara individu. Selanjutnya dapat juga diketahui apakah ketuntasan belajar secara klasikal dapat tercapai, dilihat dari persentase siswa yang sudah tuntas belajar dapat dirumuskan sebagai berikut, mencari ketuntasan belajar siswa secara klasikal dengan rumus:

$$
P K K=\frac{\text { Banyak siswa yang KKM } \geq 70}{\text { Banyak siswa keseluruhan }} \times 100 \%
$$

Keterangan

PKK = Persentase ketuntasan klasikal

Secara kelompok (klasikal), ketuntasan belajar dinyatakan telah tercapai jika sekurang-kurangnya $85 \%$ dari siswa yang ada dalam kelompok bersangkutan telah memenuhi kriteria ketuntasan minimal per individu sebesar $\geq 70$ (Suryosubroto 2009: 64).

\section{Pembahasan}

Berdasarkan hasil tindakan awal yang dilakukan pada siswa kelas III SD Negeri 47/IV Kota Jambi. Permasalahan yang dialami, siswa kurang berminat dalam melakukan gerak dasar, maka dilaksanan pembelajaran bermain kata sandi. Dari 24 siswa terdapat 11 siswa $(45,8)$ yang telah mencapai tingkat ketuntasan belajar dengan nilai rata-rata persentase 61,2 Hasil dari siklus I terdapat 18 siswa (75\%) dari 24 siswa, yang telah mencapai tingkat ketuntasan belajar dengan nilai rata-rata persentase hasil belajar siswa 264,7. Di siklus II terdapat 22 siswa $(91,7 \%)$ dari 24 siswa yang telah mencapai tingkat ketuntasan belajar dengan nilai rata-rata persentase hasil belajar siswa278,7 dapat dilihat bahwa hasil belajar siswa dari tes awal sampai dilakukannya siklus I dan siklus II terjadi peningkatan, dapat dikatakan menggunakan pembelajaran bermain kata sandi dapat meningkatkan hasil belajar gerak dasar siswa.

Berdasarkan deskripsi data penelitian, maka pada penelitian ini didapatkan hasil sebagai berikut:

Setelah pemberian tindakan pada siklus I sebanyak satu kali pertemuan, siswa diberikan tes hasil belajar I yang kemudian diperoleh sebanyak 18 orang siswa telah mencapai tingkat ketuntasan belajar sedangkan 6 orang siswa belum mencapai tingkat ketuntasan belajar yang diharapkan. Pada siklus I diperoleh data dengan rentang nilai 40 sampai 80 dengan skor rata-rata 68,7 dan persentase nilai rata-rata $64,7 \%$ serta tingkat ketuntasan belajar klasikal siswa sebesar $75 \%$ namun belum memenuhi kriteria ketuntasan secara klasikal yang diharapkan yaitu $85 \%$. Dikarenakan ada beberapa faktor siswa tersebut belum bisa mencapai tingkat ketuntasan belajar yaitu kurang pahamnya siswa dengan proses melakukan gerak

PJKR_

http://jurnal.unimed.ac.id/2012/index.php/jpehr/index 
dasar melempar dengan baik. Kemudian setelah diberikan tindakan pada siklus II sebanyak satu kali pertemuan, siswa kembali diberi tes hasil belajar II yang kemudian diperoleh sebanyak 22 orang siswa yang telah mencapai ketuntasan dalam belajar dan 2 orang siswa masih belum tuntas, dikarenakan siswa yang belum tuntas tersebut belum mampu memahami rangkaian pelaksanaan gerak dasar melempar dengan baik. Pada siklus II diperoleh data dengan rentang nilai 40 sampai 90 dengan skor rata-rata 77,9 dan persentase nilai rata-rata $78,7 \%$ serta tingkat ketuntasan belajar klasikal siswa sebesar 91,7\%. Ini berarti terlihat ada peningkatan dari siklus ke siklus. Peningkatan persentase nilai rata-rata hasil belajar siswa dari tes sebelumnya yaitu 14 dan peningkatan ketuntasan klasikalnya sebesar $16,7 \%$.

Dari analisis data yang telah dilakukan dapat disimpulkan bahwasannya dengan menggunakan bermain kata sandi dapat memberikan pengaruh serta meningkatkan hasil belajar gerak dasar. Dimana terlihat hasil belajar siswa dari tes hasil belajar I dapat meningkatkan hasil belajar gerak dasar. Dimana pada tes hasil belajar I didapat hasil penelitian yaitu persentase nilai rata-rata sebesar $64,7 \%$ serta tingkat ketuntasan belajar klasikal siswa sebesar 75\% namun belum memenuhi kriteria ketuntasan secara klasikal yang diharapkanyaitu $85 \%$. Dikarenakan yaitu kurangnya gerak motorik anak sehingga pada siklus I banyak yang belum tuntas. Untuk selanjutnya perlu diadakannya perbaikan pada tindakan pada siklus II. Pada siklus I guru menemukan banyak kesulitan yang dialami siswa dalam pembelajaran diantaranya:

1. Masih ada siswa yang belum memahami gerak dasar dengan baik yaitu pada gerakan-gerakan pelaksanaan dari lima bentuk gerakannya. Walau telah diberikan perlakuan pada siklus I siswa menggunakan bermain kata sandi.

2. Untuk menyelesaikan masalah pada siklus I maka penulis akan menambah bentuk permaianan dengan kata sandi dengan harapan masalah pada siklus I dapat teratasi. Dari tes hasil analisis yang dilakukan disimpulkan bahwa telah terjadi peningkatan kemampuan siswa. Peningkatan ini terjadi setelah diberikan pembelajaran dengan menggunakanbermain kata sandi yang dirancang pada setiap siklus. Pada tes hasil belajar II diperoleh hasil penelitian yaitu persentase nilai rata-rata sebesar $78,7 \%$ serta tingkat ketuntasan belajar klasikal siswa sebesar 91,7\%. Ini berarti terlihat ada peningkatan dari siklus ke siklus. Peningkatan persentase nilai rata-rata hasil belajar siswa dari tes sebelumnya yaitu 14 dan peningkatan ketuntasan klasikalnya sebesar $16,7 \%$ dan pada siklus II didapat hasil bahwa kriteria ketuntasan belajar secara klasikal yang diharapkan telah tercapai.

Namun masih ada beberapa siswa yang belum memperoleh ketuntasan belajar per individu walaupun nilai yang diperoleh sudah meningkat dibandingkan pada siklus I. Untuk memperbaiki masalah siswa tersebut dikembalikan kepada guru pendidikan jasmani untuk meningkatkan hasil belajar siswa tersebut.

Penguasaan gerakan dalam setiap cabang olahraga merupakan kunci utama dalam meraih keberhasilan, demikian pula halnya dalam gerak dasar.

PJKR_

http://jurnal.unimed.ac.id/2012/index.php/jpehr/index 


\section{Simpulan}

Dari hasil penelitian, hipotesis dan pembahasan hasil penelitian maka dapat ditarik kesimpulan bahwa pembelajaran bermain kata sandi berpengaruh terhadap hasil belajar gerak dasar pada siswa kelas SD Negeri 47/IV Kota Jambi.

\section{Rujukan}

Arikunto Suharsimi, 2002. Prosedur Penelitian Edisi Revisi V. Jakarta: Penerbit Rineka Cipta.

Aminarni, kk, 2007. Penjas Orkes Untuk SD Kelas III. Jakarta: Penerbit Erlangga.

Daryanto, 1997. Kamus Umum Bahasa Indonesia. Jakarta: Penerbit Rosda Karya. Kirkendall, 1987. Measurement and Evaluation For Physical Educators (Second Edision). USA: Human Kinetics Publishers, Ine Champaign, Ilinois.

Kiram, 1992. Belajar Gerak. Jakarta: Dekdikbud (Proyek Peningkatan Tenaga Pendidikan).

Matakupan, 1993. Pengaruh Bermain. Jakarta: Penerbit Rineka Cipta.

Muhajir, 2002. Pendidikan Jasmani Teori dan Praktek SD. Jakarta: Penerbit Erlangga.

Purwadarminta, 1997. Kamus Bahasa Indonesia. Jakarta: Penerbit Balai Pustaka.

Riduwan, 2004. Belajar Mudah Penelitian Untuk Guru-Karyawan dan Peneliti Pemula. Bandung: Penerbit Alfabeta.

Sukintaka, 1992. Teori Bermain Untuk D-2 PGSD Penjaskes. Jakarta: Depdikbud Dirjen Dikti, Proyek Pembinaan Tenaga Pendidik Tenaga Guru.

Sudarno, 1992. Pendidikan kesegaran Jasmani. Jakarta: Departemen Pendidikan Dan Kebudayaan.

Sudjana, 1998. Metoda Statistika. Bandung: Penerbit Tarsito. 1992. Metoda Statistika. Bandung: Penerbit Tarsito.

Sutarman, 1975. Pengertian Kesegaran Jasmani dan Tes Kardiorespirasi, Concepts of Scineces. Ed.Sic. Swanpo dan Marry W. Sic. Jakarta: KONI. 